\title{
"ÍDOLOS TRAS LOS ALTARES": A (RE)CONSTRUÇÃO DA ARTE MEXICANA NO PERÍODO PÓS-REVOLUCIONÁRIO
}

\author{
Fabiane Tais Muzardo ${ }^{1}$
}

${ }^{1}$ Universidade do Norte do Paraná, Londrina/PR, Brasil

No início dos anos 1920, a antropóloga, escritora, editora e tradutora de livros Anita Brenner convidou os fotógrafos Tina Modotti e Edward Weston para participar de um projeto que visava registrar a arte folclórica e religiosa mexicana. Inicialmente ligado à Universidade Nacional Mexicana, tal projeto resultou na produção de "Idols Behind Altars", publicado pela primeira vez no ano de 1929, nos Estados Unidos, pela editora Payson \& Clarke. Nos Estados Unidos, o livro teve várias reedições, sendo a mais atual datada de 2002. No México, o livro foi publicado uma única vez, no ano de 1983, pela Editorial Domés S.A, com o título de "Ídolos tras los altares". O presente texto utilizou como referência a edição em espanhol por se tratar da única já publicada, pela estética do livro que, desde a capa, remete à primeira edição, e pela forma como as imagens foram publicadas, em folhas separadas do corpo do texto, com papel diferenciado. Este livro, hoje, é considerado uma obra rara.

Esse projeto teve início no ano de 1923, com as viagens pelo interior mexicano, e se estendeu até 1929, quando o livro foi publicado. Brenner, Modotti e Weston viajaram por aproximadamente quatro meses por todo o país, iniciando a expedição pela região de Oaxaca. Centenas de fotografias foram produzidas, mas nem todas entraram para o livro devido ao alto custo para sua produção.

"Ídolos...", nas palavras de Alicia Azuela (2006)ํㅜ , é uma obra pioneira por ter sido o primeiro livro especializado sobre o "Renascimento Cultural Mexicano" e por ter difundido, também pela primeira vez, esse momento da arte mexicana pelo exterior. Para Azuela, o livro é primordial na construção do binômio renascimento artístico-revolução mexicana, que ainda alimenta o imaginário tanto de mexicanos quanto de estrangeiros. A autora argumenta que o livro traz uma riqueza de documentos da época porque evidencia e interpreta a visão que os autores têm do mexicano, sua história e sua arte, pretendendo dar uma visão geral e multidimensional do México a partir de 
uma perspectiva antropológica. Segundo Azuela, no livro pode-se verificar a influência da antropologia de Franz Boas e, principalmente, de Manuel Gamio $^{2}$, considerado por vários estudiosos, incluindo Brenner, o "pai da antropologia mexicana". Ele e Brenner foram alunos de Boas na Universidade de Columbia, nos Estados Unidos, entre os anos de 1927 e 1930. Apesar das afirmações de que "Ídolos..." segue a teoria de Gamio, pretende-se interpretar esta fonte sem reiterar o discurso autorreferencial do livro e dos que o estudaram, ampliando a discussão sobre esse complexo material. Vale lembrar que, nesse período, as políticas públicas mexicanas, a educação e a arte passaram por inúmeras transformações. Nesse sentido, nos parece insuficiente analisar a complexidade de "Ídolos..." somente a partir da visão antropológica de Gamio.

"Ídolos...", dentre tantas transformações, se inseriu em um contexto em que a política da mestiçagem, idealizada por José Vasconcelos ${ }^{3}$, vinha sendo substituída pela política indigenista, ligada diretamente às discussões feitas por Gamio na primeira década do século XX. Acredita-se que isto ajude a entender o fato de normalmente os estudos relacionarem "Ídolos..." à política indigenista. Contudo, muito da mestiçagem de Vasconcelos se faz visível no livro. Além disso, apesar de, em 1924 a mestiçagem ter saído da cena política oficial mexicana (devido à renúncia de Vasconcelos do cargo de Secretário da Educação), em 1925 ocorreu o lançamento do livro "La Raza Cósmica", principal obra defensora da mestiçagem, de autoria de Vasconcelos, ou seja, a década de 1920 não pode ser vista de modo engessado, ligada à mestiçagem ou ao indigenismo, pois as duas teorias estavam presentes nesses anos. ${ }^{4}$

Partindo desses apontamentos, este artigo tem o objetivo de analisar o livro "Ídolos tras los altares" com base nos diálogos que ocorriam no México sobre a questão indígena e cultural.

\section{Mestiçagem e indigenismo: concepções acerca do povo mexicano no início do século $\mathrm{XX}$}

Alguns estudos sobre "Ídolos..." defendem a ligação da obra com a teoria antropológica de Gamio, conforme mencionado. Azuela (2006) afirma que a teoria do relativismo cultural, de Boas, foi utilizada por Gamio, no México, para se contrapor à ideia evolucionista em voga naquele período. Defende, portanto, que Brenner se valeu, em "Ídolos...", da teoria do relativismo cultural para pensar sobre a história e a vida do povo mexicano. Em vários momentos, de fato, pode-se perceber essa ligação. O próprio título do livro, segundo Azuela (2006), teria sido escolhido por Brenner a partir da ideia de 
Gamio de sobreposição de culturas. Contudo, diferentemente do que costuma ser afirmado por pesquisadores como Eduardo San José Vázquez (2009) e a própria Azuela (2006), a presente análise parte da ideia de que "Ídolos..." não se encaixa perfeitamente à teoria de Gamio. "Ídolos..." transcende a teoria de Gamio, ligando-se, às vezes, à mestiçagem de Vasconcelos, à teoria boasiana ou ainda criando novas perspectivas. Isto sem mencionar o fato de que Gamio, em suas obras, muitas vezes deixou de lado a perspectiva do relativismo cultural, do qual ele se dizia defensor e propagador, desenvolvendo uma análise muito mais próxima do evolucionismo.

Várias correntes teóricas coexistiram no México no período pósrevolucionário. As principais foram o positivismo, as ideias ligadas ao "Ateneo de la Juventude"5 e o indigenismo, criado por Gamio. Apesar de divergirem em muitos aspectos, em alguns pontos tais correntes se aproximavam, como no que se refere à importância da educação, ainda que não concordassem com os objetivos e os métodos do processo. A doutrina positivista ganhou força no México, a partir do governo ditatorial de Porfirio Diaz (1884-1911), quando se passou a enaltecer a grandiosidade dos indígenas antes da Conquista e a realçar a decadência em que se encontravam no século XX. Acreditava-se, então, que a educação poderia ser a propulsora de uma nova condição para a população indígena. Contudo, essa educação não visava ao reconhecimento, muito menos à valorização da cultura indígena, e sim à inserção destes no que era concebido, naquele momento, como a cultura moderna. O indígena, portanto, era rotulado como um entrave ao progresso da nação que se desejava construir.

Andres Medina (1974) destaca a ação do governo de Diaz nessa busca por aculturar o indígena, afirmando o discurso por parte do governo no sentido de destacar repetidamente a triste condição do indígena no século $\mathrm{XX}$, em contraposição ao esplendor que existia antes da Conquista. Essa visibilidade/invisibilidade do indígena durante a ditadura de Diaz também é discutida na obra "Historia de la vida cotidiana em México" (Reyes, 2006). Em um dos artigos, escrito por Alberto del Castillo Troncoso, ressalta-se o fato de, durante as comemorações do centenário de Independência do país, Diaz ter ordenado a prisão dos indígenas que perambulavam pelas ruas centrais da cidade. Assim, ao mesmo tempo em que se defendia, ao menos teoricamente, que o indígena era parte da cultura nacional, reconhecendo-o como integrante da nacionalidade mexicana, como afirma Medina (1974), visava-se deixá-lo invisível socialmente, até o momento em que seus aspectos identitários não mais diferissem do que se esperava de um país moderno. É por isso que se considera que começou a existir uma maior preocupação com a questão indigenista no país a partir da criação da antropologia mexicana, 
em que Gamio se destacou. Contudo, apesar de aumentar a visibilidade dos indígenas, a teoria antropológica de Gamio tinha elementos no mínimo questionáveis.

Gamio encarou a Revolução de 1910 como a possibilidade de rever a situação em que se encontravam os indígenas mexicanos, de modo que, por meio da atuação do Estado, eles pudessem ser inseridos na cultura nacional. Pode-se dizer que em sua teoria antropológica destacam-se a abordagem integral, baseada no método boasiano, e a importância dada à escola rural. Entretanto, apesar de se aproximar de Boas quanto à integralidade, Gamio partilhava ideias positivistas em muitos sentidos. Segundo Guillermo Castillo Ramírez (2013), da teoria boasiana, Gamio se utilizou da crítica à perspectiva mecânica e acumulativa do progresso, o questionamento das concepções de superioridade racial de uma sociedade em relação à outra e a necessidade de se investigarem os diversos grupos humanos a partir de diferentes perspectivas: etnográfica, arqueológica, linguística e histórica denominada por ele de investigação integral.

Entretanto, apesar de o próprio Gamio declarar que se baseava nesse método de análise, em "Forjando Patria. Pro nacionalismo", publicado em 1916, ele rompeu com cada um desses pontos ao realizar sua análise. Nas primeiras páginas desta obra, por exemplo, Gamio analisou os países que, segundo ele, tinham uma nacionalidade definida e integrada: Alemanha, França e Japão. Nesta afirmação inicial já se percebe um afastamento do relativismo cultural proposto por Boas. Segundo Gamio, estes três países formavam nações por terem três características básicas: unicidade étnica, convergência de manifestações culturais e equilíbrio econômico. Com base nesse modelo estrangeiro, Gamio defendeu a criação de tais condições para que o México também se tornasse uma nação.

Em artigo para a primeira edição da revista "Mexican Folkways"6, de junho/julho de 1925, Gamio escreveu, de acordo com sua visão, sobre a necessidade de os especialistas, homens cultos em geral e os governantes conhecerem o folklore mexicano para, a partir dele, tirar conclusões acertadas que servissem para elaborar regras de governo. Isto seria mais necessário, na sua acepção, em países como o México, em que a maioria da população - indígena e mestiça - estaria em etapas culturais mais ou menos primitivas. Esse conhecimento, para Gamio, serviria para elaborar meios educativos que possibilitariam a integração desses povos ao pensamento moderno, o que não significaria que houvesse o desejo de se retirarem dos indígenas suas características típicas, com destaque para a arte. Contudo, haveria a necessidade de agir para que eles saíssem "de una etapa de obscurantismo, de miséria orgânica y de malestar general a otra de conocimiento y de 
bienestar intelectual y material" (Gamio 1925: 9-10). É possível perceber, desse modo, no discurso de Gamio, um posicionamento que hierarquiza as culturas mexicana e europeia, de modo divergente do relativismo cultural que dizia defender.

Outro teórico mexicano, José Vasconcelos, tem no conceito de "raça cósmica" uma de suas principais criações (1925). Também discutindo a questão cultural, mas em outra perspectiva, Vasconcelos defendeu que as raças do mundo tenderiam a fundir-se, mesclar-se cada vez mais, até formar um novo tipo humano, a "raça cósmica", que seria o resultado da união de todas as raças, e não de uma hierarquização delas. Este é um dos maiores destaques da concepção de Vasconcelos: propor algo igualitário em um momento em que sobressaía, no campo científico, o darwinismo, e sua adaptação ao terreno social, o darwinismo social. Seguindo a concepção de Vasconcelos, o aspecto educacional seria o fomentador de uma melhoria econômica, que colaboraria para possibilitar a igualdade entre os grupos, ao contrário da visão de Gamio, para quem o desenvolvimento de condições materiais de existência era um fim e não um meio. Vasconcelos destacou que, no México, a mestiçagem total das raças não aconteceu devido à exclusão dos espanhóis após o processo de Independência. O autor explicou esse processo de mestiçagem defendendo a existência do que denominou de quatro troncos: negro, amarelo, vermelho e branco. Na concepção de Vasconcelos, o branco, a partir do momento em que invadiu o restante do mundo, serviu como ponte entre todas as raças.

Diferentemente da concepção de Gamio, para Vasconcelos, o indígena entraria na cultura moderna sem precisar da "ajuda" do europeu. $\mathrm{Na}$ verdade, nesse momento o indígena já não seria mais puramente indígena, como o europeu não seria puramente europeu. Interessante também que, para Vasconcelos, ocorreu uma real mistura dos elementos que até então caracterizavam cada um desses povos individualmente, e não algo unilateral como defendeu Gamio. Nesse sentido, Vasconcelos viu o indígena e se percebeu como aquele que existia a partir da fusão das culturas indígena e europeia, diferentemente de Gamio, que sempre viu o indígena como "o outro". Para Vasconcelos, o fato de a colonização espanhola ter gerado mestiçagem era o diferencial que faria com que as ações desse novo tipo humano cumprissem o seu dever de constituir a "raça cósmica", diferentemente dos outros povos que se projetaram na história em outros momentos, mas sem conseguirem se manter enquanto povos dominantes, justamente pela homogeneidade de suas raças. Para ele, os próprios brancos, descontentes com a busca desenfreada por bens materiais e com a injustiça social que eles próprios criaram, acabariam por procurar ajuda junto às demais raças. 
Note-se, contudo, que este aspecto da teoria de Vasconcelos também segue um caráter evolutivo, ao defender a passagem por diferentes estágios, dos mais simples aos mais evoluídos. Além disso, há um caráter utópico, pois aquilo que Vasconcelos visualizou como "raça cósmica" seria o estágio mais sofisticado, baseado na sensibilidade e na estética. Percebe-se, desse modo, que as visões de Gamio e Vasconcelos sobre os indígenas mexicanos se afastam em inúmeras perspectivas, apesar de ambas se pautarem por uma ideia de progressão (uma teleologia), indicando uma necessidade de se passar por diferentes etapas até se chegar a um "fim" desejado. "Ídolos...", nesse meio, às vezes se aproxima da teoria de Gamio, às vezes da teoria de Vasconcelos, às vezes de nenhuma delas, conforme analisaremos a seguir.

\section{Estrutura de "Ídolos tras los altares"}

Estruturalmente, o livro de Brenner divide-se em três partes, a partir de uma abordagem cronológica: México pré-hispânico, colonial e moderno. Em cada uma das partes a autora mescla crônicas populares, resultados de sua observação, descobertas e suas próprias lembranças. Na introdução, Brenner apresenta a metodologia escolhida, esclarecendo se tratar de um livro que parte de uma perspectiva antropológica, não sendo, portanto, nem um livro de crítica nem de história da arte. Nesse sentido, a teoria de Boas, do relativismo cultural, se faz presente na obra como um todo. O fato de o livro ser, ao mesmo tempo, resultado de análises antropológicas com visões pessoais, contendo trechos de conversas, lendas e contos populares, faz com que o caráter pessoal e encantado de seus produtores se torne evidente. De modo geral, na primeira parte, que trata do México pré-hispânico, Brenner mistura elementos artísticos com lendas e descrições de paisagens, destacando as tradições dos diferentes grupos humanos. "De acuerdo con Brenner esas características siguieron vivas entre los indígenas, se fundieron con las nuevas formas traídas del viejo continente y se encarnaron sobre todo en el arte popular" (Azuela 2006: 79).

Na segunda parte, sobre o período colonial, Brenner caracteriza a personalidade dos indígenas e dos espanhóis. Segundo Azuela (2006), a narração de Brenner sobre a colonização se assemelha à visão que Diego Rivera desenvolveu nas paredes do Palácio Nacional. 
La conquista marca el principio del sincretismo, el mestizaje y la superposición de culturas, en las que sigue viva la religión indígena con sus ídolos ocultos tras los altares, que burlan la imposición de las creencias cristianas. Cuando describe las guerras de independencia, Anita señala que en siglo se perdio en el terreno cultural mucha de la originalidade que se habia alcanzado durante la colônia, porque se afranceso el gusto de las elites (Azuela 2006: 83).

Brenner finaliza esta parte do livro destacando a arte popular, ao defender que somente nela se mantiveram as tradições artísticas indígenas, criando uma mestiçagem cultural.

Na terceira parte, Brenner aborda o período revolucionário, ao defender a ligação entre a revolução e o que chamou de Renascimento Cultural. Os capítulos desta parte do livro são organizados, na maioria das vezes, a partir do nome dos artistas muralistas mexicanos.

Um artigo sobre "Ídolos..." foi publicado na revista "Mexican Folkways", no ano de 1929. Nele, Brenner foi chamada de Vasari ${ }^{7}$ da moderna escola mexicana, destacando sua postura crítica e sua visão. O autor do texto, não identificado, afirma que a arte é o ponto central da obra. Para Brenner, a arte tem uma dimensão ampla: trata-se da própria vida mexicana. A autora trabalha, portanto, com a concepção de vida/arte mexicanas como instâncias não possíveis de serem separadas. O artigo fez duas críticas à "Ídolos...", uma por não concordar com o fato de conter mais páginas sobre Goitia do que sobre o "majestoso Diego Rivera", o que, contudo, tem total relação com o fato de ela entender, e os próprios artistas mencionarem tal ponto em determinados momentos, que o trabalho desenvolvido nos murais se tratava de algo muito mais voltado para o coletivo do que para o individual; no qual, mais do que fama e assinaturas, visava-se produzir algo público. Desse modo, abordar artistas menos conhecidos, como Goitia, tem total sentido. Vale lembrar que a primeira edição do livro foi publicada nos Estados Unidos, onde Rivera já era muito conhecido.

A segunda crítica diz respeito às inconsistências que o autor afirma que "Ídolos..." possui, ao escolher, por exemplo, a vacilada ${ }^{8}$ como um dos principais símbolos indígenas, sendo que a vacilada é marcadamente mestiça. Este ponto, contudo, pode ser utilizado para validar nosso argumento de que "Ídolos..." parte de uma visão muito mais ampla da vida/arte mexicana do que defendiam autores como Gamio e Vasconcelos. Brenner, obviamente, sabia que a vacilada era mestiça, mas escolheu-a para simbolizar o indígena, uma vez que ela carregava, e ainda carrega, o elemento indígena, que sobreviveu se mesclando ao espanhol. Ao invés de separações engessadas, há fluidez. De acordo com o artigo da revista, 
At bottom she is vitally interested in the reemergence of the Indian culture. She is quite aware of the psychological, aesthetic and social diferences between Indian and mestizo, between dark skin, and White; but she does not clearly disentangle.

Perhaps Brenner, to sustain her preoccupation with Indian reemergence should have chosen the "petate" rather than the "vacilada" as her dominant symbol. Yet instinctievely she has been wise in her inconsistency (Mexican Folkways 1929: s/p; autor desconhecido).

Nota-se o diferencial do olhar de Brenner: tratar um elemento marcadamente mestiço, a vacilada, como aquele que torna presente o elemento indígena, ou, dito de outro modo, a permanência da presença indígena apesar da conquista, da tentativa de imposição cultural, do choque cultural. A vacilada aparece novamente nos escritos de Brenner sobre as pulquerias, as quais serão analisadas posteriormente.

Na revista, o artigo ainda ressaltou a importância dos vários registros sobre o trabalho dos pintores e a criação do Sindicato de Pintores e Escultores apresentados em "Ídolos...", os quais o mundo algum dia ainda irá agradecer. "Yet all in this book is a glorious record of a glorious decade in the history of the world's great painting" (Mexican Folkways 1929: s/p). Concordamos com o artigo de "Mexican Folkways" no que diz respeito ao interesse de Brenner pelo renascimento da cultura indígena. Contudo, divergimos quanto à forma de entender esse renascimento. Mais do que início, fim e reinício, vemos o renascimento cultural criado por Brenner a partir de uma concepção warburguiana, baseada na noção de nachleben. Na visão warburguiana, "toda cultura é essencialmente processo de transmissão e de Nachleben - criação e revolução atuam, em geral, "polarizando" os dados fornecidos pela tradição, até chegar, em certos casos, à sua total inversão semântica" (Agamben 2007: 186-187).

\section{México pré-hispânico: aproximações e distanciamentos das teorias de Gamio e Vasconcelos}

O primeiro capítulo de "Ídolos..." intitula-se "El Mesías mexicano". Brenner o inicia apresentando uma velha profecia popular que prega que os antigos direitos dos ancestrais voltarão a existir quando o templo maior dos astecas aparecer novamente na praça principal da cidade de Tenochititlán. Ocorre que, em 1926, em meio a uma obra no Palácio Nacional, um facsímel de um templo asteca foi encontrado. A profecia, de certo modo, se efetivou. A menção a essa profecia já cria uma ideia da forma como Brenner trabalha 
com a história mexicana. Ressaltando a singularidade do país, ela destaca as diferentes condições geográficas, econômicas e de gênero, dentre outras, que caracterizam o México, afirmando tratar-se de um país que não teria necessidade de ser decifrado historicamente, pois explica a si mesmo não enquanto uma nação em desenvolvimento, mas como uma imagem.

A noção de movimento se faz presente no capítulo como um todo. O interessante é que Brenner trabalha com o movimento e o repouso ao mesmo tempo, como se a vida se movimentasse eternamente, mas sempre se mantivesse a mesma. Nota-se que, apesar de o livro ser organizado cronologicamente, esta primeira parte, que trata do período pré-hispânico, faz referência à Revolução de 1910. Constantemente se misturam os momentos da história do México, sendo a Revolução e o período pós-revolucionário os maiores marcos de discussão. Desse modo, a organização cronológica, primeira característica que se nota no livro, não é engessada, estando também muito mais voltada para a ideia de constantes renascimentos do que de linearidade. Nas palavras de Brenner, o México

es una película de historia humana que puede verse de atrás para adelante, aunque con frecuencia es difícil saber quién es el selvage. Si Nueva York es un despliegue de razas, México acuna todas las edades. Se viaja de la capital a la sierra y de un salto se viaja a 1850 y 1972 y 1500, y de allí a los anos neolíticos sin fecha. E incluso en la capital puedes ver, si observas con atención, los días de tu abuela y cosas feudales y medievales, vislumbres de la antigua conducta Cristiana y rostros arcaicos; y también las presencias materiales de la belleza de cada época (Brenner 1935 citada em Monsiváis 2006: 19).

Brenner trabalha com a concepção de morte e renascimento como algo orgânico ao pensamento do mexicano. Para ela, tal preocupação "surge como una motivación en el arte desde de la Conquista, sobrevive durante todo el período colonial y reaparece una y otra vez hoy en día" (Ugalde 2006: 18). Essa constância se comprovaria, na sua visão, perante a existência de um dia dos mortos, por exemplo, que, apesar de ter sido oficializado pelos cristãos, existia desde muito antes entre os mexicanos. Essa "presença" constante, essa sobreposição de culturas e tempos, é discutida por Antonio Guerreiro, autor que analisa a concepção warburguiana como uma história da arte que se volta não para o que se altera, e sim para o que permanece, "sob a forma de uma energia viva da memória social, inculcada na fórmula de páthos" (Guerreiro 2012: 4). Entende-se páthos como uma fórmula de intensidade do passado que permanece, voltado não para uma memória consciente, mas sim para aquilo que "se esquece", ligada à concepção nietzschiana do eterno retorno e da necessidade de esquecimento. 
Para Warburg, portanto, a imagem é um híbrido, de matéria e de forma, de criação e de performance, singularidade inaugural e repetição.

A ligação do mexicano com a morte é, na realidade, para Brenner, uma preocupação com a paixão pela vida. Paixão que os artistas tentavam transformar em imagens. Nesse momento, Brenner, além de realçar a presença das caveiras nas artes e na própria vida mexicana, destaca, também, a presença das mãos, como "el símbolo del artista para significar lo creativo" (Brenner 1983: 25). A menção à mão é recorrente, tanto na narrativa quanto nas fotografias produzidas para o livro. A primeira imagem de "Ídolos...", inclusive, é uma fotografia das mãos do oleiro Amado Guzmán (Figura 1). Esta imagem é a única que teve a autoria referenciada, trata-se de uma fotografia de Weston. Todas as demais fotografias que integram "Ídolos..." não foram assinadas.

Figura 1: Mano del alfarero Amado Guzmán de Tonalá, Jalisco, Edward Weston

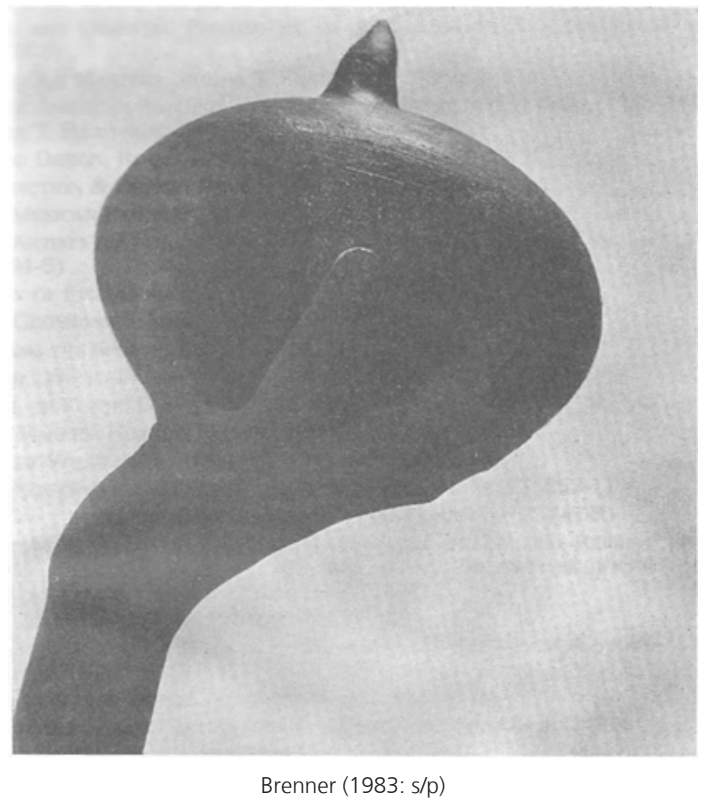

Marie-José Mondzain (2015) afirma que a criação do homem espectador, esse homem que se vê e se dá a ver, se deu a partir da mão, a qual, no interior da gruta - fazendo referência às pinturas rupestres produziu "diante dos olhos o objeto do primeiro olhar" (Mondzain 2015: 32). Em sua visão, os homens hominizados encarregaram-se do trabalho de humanizar-se, desviando suas ações das tarefas de sobrevivência, e 
experimentando uma temporalidade nova. "O gesto dentro da gruta cria o homem à imagem da sua própria mão. É o auto-retrato de um sujeito que só conhece de si e do mundo a marca que as suas mãos aí irão deixar [...] O primeiro olhar sobre o visível é obra das mãos" (Mondzain 2015: 41). São as nossas mãos, segundo Mondzain, que criam o espectador. O caráter ativo da mão também é ressaltado por Henri Focillon, que entende o rosto humano como um conjunto de órgãos receptores, e a mão como ação, que "apreende, cria, e por vezes dir-se-ia mesmo que pensa" (Focillon 2001: 108). Segundo o autor, a mão

não apenas serviu aos propósitos do ser humano, como os ajudou a nascer, os definiu, lhes conferiu forma e rosto. O homem fez a mão, isto é, resgatou-a pouco a pouco do mundo animal, libertou-a de uma escravidão antiga e natural, mas a mão fez o homem. Permitiu-lhe estabelecer certos contatos com o universo que os seus outros órgãos e partes do corpo não conseguiam (Focillon 2001: 110).

Em sua visão, os outros animais sem mãos, ainda que se desenvolvam, ficam no limiar da arte, não conseguindo construir "o seu mundo mágico" (Focillon 2001: 112).

Para Brenner, o mestiço era apaixonado pela beleza e iniciador de algo totalmente próprio. "Los cuatrocientos años transcurridos desde la Conquista han sido testigos de la disminución progresiva de la influencia directriz de los blancos, quienes abandonaron el país, murieron, o penetraron al mestizage" (Brenner 1983: 56). Nesse sentido, contudo, Brenner se aproxima muito mais do discurso defendido por Vasconcelos do que da teoria de Gamio. Enquanto Gamio defendia que as artes mexicanas se tornaram vazias, justamente por apenas transportarem algo europeu, afastado de sua realidade, Brenner defendia o oposto, dizendo que o mexicano repelia aquilo que era falso, inconsistente ou simplesmente artificial. Mas, afinal, o que se entendia por mestiçagem naquele contexto? Apesar de defenderem teorias opostas em muitos aspectos, Gamio e Vasconcelos viam a mestiçagem como algo que geraria a unicidade, a homogeneidade do mexicano. Brenner, por sua vez, apesar de certas vezes pender para uma visão da mestiçagem enquanto aquilo que geraria a unidade no povo mexicano, via tal processo como gerador de algo novo, fruto da fusão das caraterísticas europeias e nativas, não necessariamente das "melhores" características de cada um deles, como defendia Vasconcelos.

Nos dias atuais, contudo, há diversas formas de se pensar a mestiçagem. Serge Gruzinski (2007), por exemplo, defende a existência de uma realidade polimorfa, composta por identidades múltiplas e em constante metamorfose. Para Gruzinski, o conceito de mestiçagem tem o inconveniente de ser vago, 
além de remeter, a princípio, ao que não se é, a exemplo de cores básicas e corpos puros. Em nova perspectiva, Gruzinski, fazendo referência aos estudos do antropólogo mexicano Gonzalo Aguirre Betrán, defende que a luta entre a cultura europeia colonial e a cultura indígena fez com que os elementos opostos dessas culturas tendessem a se excluir mutuamente, ao mesmo tempo em que se penetravam e se identificavam, formando algo novo, "la cultura mestiza o mexicana - nacida de la interpretación y de la conjugación de los contrários" (Gruzinski 2007: 60).

De acordo com Gruzinski, um tipo peculiar de mescla ocorreu no campo das crenças e dos ritos, que também são destacados em "Ídolos..." Segundo Gruzinski, a dificuldade de se trabalhar com o intermediário, com o que está entre, leva os intelectuais a preferirem trabalhar com conjuntos monolíticos. Nesse sentido, pensar a mestiçagem tornaria imprescindível a quebra de ideias fechadas, pautadas na simples permanência de elementos indígenas e europeus de modo paralelo, ao invés de uma real fusão, em permanente mudança. Em sua visão, ao invés de um sistema definido, a história humana é marcada pela existência de uma "nebulosa en perpetuo movimiento" (Gruzinski 2007:60). O conceito de nebulosa é exatamente oposto à ideia de unicidade e homogeneidade que predominava no momento em que "Ídolos..." foi pensado e produzido. Para Gruzinski, ao invés de unicidade, a mestiçagem gera caos, justamente por criar algo nunca antes visto e que, além disso, se mantém em constante mudança. Na América, diz Gruzinski,

muito cedo as etnias se misturam, os seres, as crenças, os comportamentos se miscigenam. A América hispânica se torna assim a terra de todos os sincretismos, o continente do híbrido e do improvisado. Índios e brancos, escravos negros, mulatos e mestiços coexistem num ambiente de confrontos e trocas, no qual poderíamos nos reconhecer facilmente. América, "caos do duplo" (Gruzinski 2006: 19).

Nos textos de Brenner, essa permanente mudança se faz presente na necessidade do mexicano de viver criando, a qual, segunda ela, faz parte da própria integridade mexicana. Nesse sentido, ao mundo racional e físico o mexicano acrescentaria um sentido espiritual. Aqui, Brenner se afastaria ainda mais da teoria de Gamio, ao defender que tal singularidade do mexicano faria com que ele somente pudesse ser pensado e entendido a partir de seus próprios valores, considerando, inclusive, o povo mexicano como artista. Argumentando desta forma, Brenner analisa o valor das coisas produzidas, seus usos ou não usos, dizendo que se aquilo que o mexicano produzia era visto por ele como belo, não interessava se isso era ou não valioso ou se condizia com as expectativas dos outros. 
Sus acciones son cuestión de pasión o de gusto [...] Es por este que en ningún otro lugar como en México el arte ha sido una parte orgánica de la vida, acorde con los fines del país y la búsqueda nacional, una posesión individual y siempre la primera opción para el país y para el individuo (Brenner 1983: 31).

A ideia de reconstruir o país a partir da arte se faz clara neste fragmento e se percebe um diálogo entre as concepções de Brenner e Vasconcelos, para quem o México somente se tornaria uma nação, de fato, no momento em que superasse questões de fundo econômico e se desenvolvesse numa perspectiva estética.

Para Brenner, as primeiras produções artísticas dos mexicanos foram as esculturas de barro, que eram, ao mesmo tempo, arte e religião. Nesse ponto, Brenner afirma que essas manifestações, que ela chamou de pensamento mexicano, sempre poderiam ser rastreadas até a origem. Contudo, a nosso ver, em consonância com a perspectiva de Didi-Huberman, essa "origem" se aproxima muito mais do nachleben do que de genealogia, o que, inclusive, se avizinha da concepção de renascimento, criada pela própria Brenner.

O retorno do mesmo não é um retorno ao mesmo, muito menos um retorno ao idêntico. O "mesmo" que volta no eterno retorno não é a identidade do ser, mas apenas um semelhante. A mênade que retorna na sobrevivência das formas do Quattrocento não é o personagem grego como tal, porém uma imagem marcada pelo fantasma metamórfico - clássico, depois helenístico, depois romano, depois reconfigurado no contexto cristão - desse personagem: em suma, é uma semelhança que passa e retorna (Didi-Huberman 2013: 151). ${ }^{9}$

No lugar de concepções isoladas, de rigidez, de retorno de iguais, e de fusões homogeneizadoras, ter-se-ia, portanto, a criação de algo novo, diferente de tudo o que já existiu. A concepção de repetição seria, desse modo, não pautada em mera cópia, não em retorno do mesmo, e sim em retorno do semelhante em novas configurações, afinal se trata de um novo contexto, de uma nova situação. A arte ancestral mexicana resgatada não é original, não é pura, ela é resultado do que ficou das disputas primitivas, da conquista espanhola e da formação do Estado nacional mexicano, dentre outros elementos; é o que sobreviveu alterando-se permanentemente e que será novamente reconfigurado, agora com os olhos daqueles que viveram no período pós-revolucionário. O que retorna, portanto, ainda seguindo a concepção warburguiana, não é somente vida e beleza, mas é também dor. Dor da conquista, da dominação, da morte. 
No terceiro capítulo, intitulado "Los redentores blancos", Brenner conta a história da chegada dos europeus, retomando a profecia sobre o tempo, dos ciclos sempre marcados por catástrofes. Nesse sentido, menciona que Moctezuma, logo no início de seu governo, falava a seus súditos que seu reinado terminaria com a chegada daqueles que os transformariam em escravos. Para Brenner, o momento em que ocorreu o encontro de culturas, iniciou-se a produção de imagens sobre os espanhóis, sendo que os primeiros contatos que Moctezuma teve com os espanhóis se deram justamente a partir dessas imagens.

Contrariamente ao posicionamento de Gamio, Brenner defendeu que os europeus obrigaram os indígenas a seguir suas crenças, sendo forçados a construir igrejas, por exemplo. Em meio a essa imposição, os indígenas acabariam por adentrar na crença cristã, embora não de modo igual ao que era professado pelos conquistadores. Para a autora, os missionários religiosos eram também missionários das artes, uma vez que viam a arte religiosa indígena como ícones, os quais, para os espanhóis, eram "el trabajo del diablo" (Brenner 1983: 93). Nesse sentido, essa nova arte produzida pelos indígenas produzia uma arte cristã diferente.

El impacto de nuevos conceptos plásticos y emocionales sobre artistas altamente sensitivos, la tragédia de la conquista y el terror y dolor que le sucedieron, así como la administración española del gobierno nativo, fueron los elementos que se fusionaron para elevar la temperatura de un Renacimiento, que ya empezaba a enfriarse en Europa (Brenner 1983: 93).

Percebe-se, novamente, a menção à concepção de Renascimento como algo além do início de um novo ciclo, como aquilo que resulta da fusão de uma série de acontecimentos, de culturas diferentes. Nesse ponto, Brenner extrapola as visões de Vasconcelos e Gamio ao defender o surgimento de algo novo, criado com base na fusão de tempos diferentes, de culturas distintas. Diferentemente da visão de Vasconcelos, baseada na criação da "raça cósmica" (1925), a raça definitiva; e da de Gamio, baseada na inserção do indígena no modelo europeu e consequente homogeneidade cultural, Brenner defende o movimento incessante, o eterno renascimento da cultura, numa concepção de mestiçagem curiosamente muito mais próxima do "caos" presente na perspectiva atual de Gruzinski, entendida como uma realidade composta de identidades múltiplas e de metamorfoses constantes que, num primeiro olhar, pode gerar uma aparência de incoerência, mas que, ao contrário, não tem nada de contraditório, uma vez que "la verdadera continuidad de las cosas habita en el corazón de la metamorfose y de lo precário" (Gruzinski 2007: 33). 


\section{México colonial: as sobrevivências do período colonial no México de 1920}

Brenner inicia a segunda parte do livro contando sobre uma noite em que conversou com um vendedor na Cidade do México. Falavam sobre os pintores enquanto contavam estrelas e cantavam corridos. ${ }^{10}$ A singularidade e a intimidade do livro se fazem latentes nesses momentos. Brenner cria diálogos, aproximando o leitor daquilo que conta. Menciona que, ao final de uma estrofe, um tejedor se inseriu na conversa contando que tinha acabado de apunhalar um homem, pois estavam em desacordo sobre assuntos da terra. Nas palavras de Brenner, não se questionou o assassinato, pois "el tejedor es una buena persona, digno de confianza. Vive en un pueblo cercano y hace los mejores sarapes de la región" (Brenner 1983: 113). A disputa ligava-se a títulos de terra. Ocorre que o homem assassinado também era indígena, o que, para Brenner, gerava dúvidas quanto à compreensão do ocorrido, pois qualquer pessoa externa à realidade dos indígenas poderia descrevê-los fisicamente, detalhar os modos de vida e as coisas que possuíam, porém "el hombre continuará incomprensible e intacto en su propio material" (Brenner 1983: 116), ou seja, não poderia compreender o modo como a terra é referência de toda a sua vida, pois o indígena "piensa, siente y se comporta, de principio e fin, sustentado en la tierra" (Brenner 1983: 116).

Tudo se liga a terra, direta ou indiretamente. A cabana, por exemplo, é um símbolo do habitar. Significa, portanto, um lugar, o que automaticamente implica um pedaço de terra. Nesse sentido, vale destacar que uma das poucas fotografias de "Ídolos..." que faz referência mais diretamente à presença humana, trata exatamente desse morar. Essa imagem (Figura 2) é a última fotografia que compõe a primeira parte do livro. Retrata o interior de uma casa indígena em Xochimilco, mesmo lugar ao qual Brenner se referiu ao contar sobre a conversa com o vendedor. Trata-se de uma moradia nativa, feita de palha, onde existem símbolos que remetem a um aspecto religioso já alterado por meio da fusão das culturas nativa e europeia. Alguns objetos de uso cotidiano também compõem a fotografia, como panelas, uma cadeira e uma mesa. Somente o interior da cabana foi fotografado, nada mais. Contudo, a composição da imagem cria uma aura de intimidade. Por um instante, parece que entendemos o modo de vida dos indígenas, parece que fazemos parte de seu mundo. 
Figura 2: Interior de uma casa indígena. Xochimilco

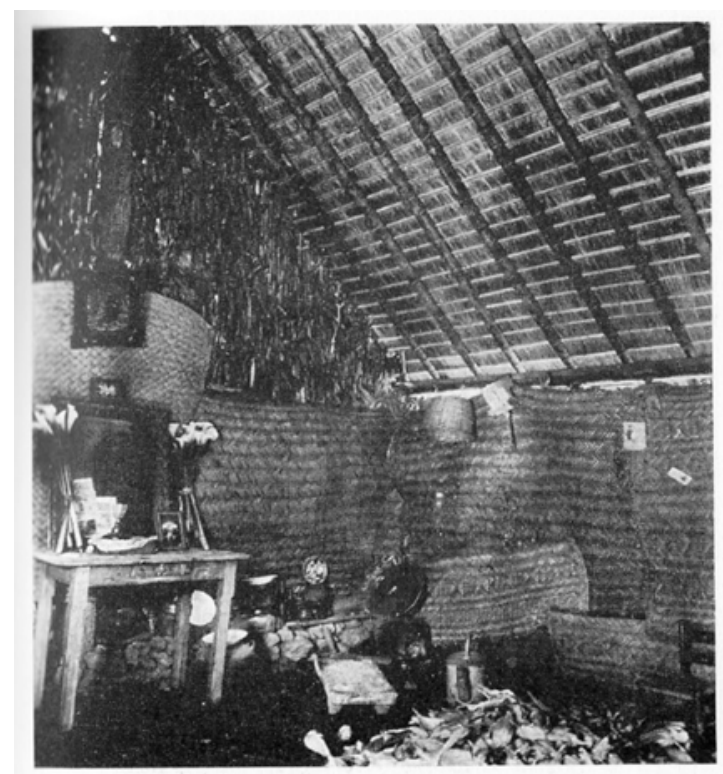

Brenner (1983: s/p)

Essa concepção voltada para a terra, como aquela que está presente em tudo e centraliza a vida das pessoas - basta pensar nos dizeres de Brenner sobre o indígena que pensa, sente e se comporta sustentado pela terra -, é notável não somente no modo de vida dos nativos, mas também na arte produzida no México. Em um mural da Secretaria de Educação Pública SEP - (Figura 3), produzido na década de 1920, por exemplo, Rivera articula imagem e palavras de modo a estabelecer uma relação entre a terra e o trabalho coletivo. A menção a terra é constante nos contos, nos corridos, no cotidiano e nas artes mexicanas. O mural de Rivera traz, também, referência à mão. 


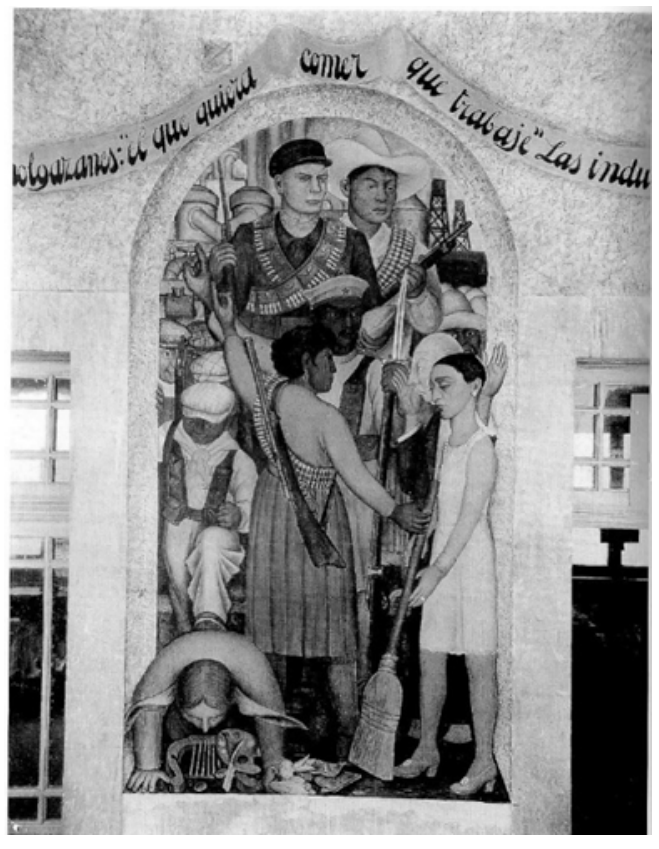

Manjarrez (1999: 48)

A terra, portanto, é aquilo que centraliza a vida dos indígenas. Vive-se na e para a terra, diferentemente daqueles que a veem como um símbolo do poder. Partindo desta concepção, Brenner inicia uma severa crítica à situação dos indígenas, fazendo referência a um historiador mexicano, não nomeado, que afirmava que os indígenas tinham melhorado muito com a conquista, já que os espanhóis foram responsáveis, dentre outras coisas, por levar para o México bestas de carga, enquanto os mexicanos lhes deram homens de carga. "La imagen de una actitud nativa por excelência. Los libros pintados de los astecas muestran hombres agachados bajo el peso de cargas enormes, el triple de tamaño de su persona" (Brenner 1983: 131). Em face desta imagem, discute-se a questão da terra no México, destacando aqueles que não a possuíam e o estranhamento que causava a utilização da terra como objeto de troca, pois essa prática era como "traficar con la propia madre y negar el principio fundamental de la vida" (Brenner 1983: 131). Nesse momento, novamente a autora deixa de lado o caráter cronológico da estrutura do livro e faz menção ao governo ditatorial de Diaz e sua ação de ignorar títulos de terra outrora outorgados pela Coroa espanhola, numa nova violação aos direitos indígenas. 
Ao abordar a cultura popular, Brenner destaca a importância das pulquerias $^{11}$ e a ancestralidade do pulque, produzido a partir do maguey ${ }^{12}$, considerada uma planta sagrada. Para ela, é impossível falar do indígena ou do espanhol de modo individualizado no que se refere aos nomes das pulquerias. Trata-se do mexicano. Nome e imagem andam juntos, neste caso. As imagens que compõem as paredes das pulquerias são, nas palavras da autora, uma arte viva, na medida em que, pela baixa qualidade dos materiais com que eram produzidas, precisavam ser constantemente refeitas, o que acabava por garantir uma clientela constante. Trata-se, desse modo, de uma arte pública no seu sentido mais literal: arte nas ruas.

Figura 4: Fotografia da fachada da pulqueria. "Los amores de Cupido"

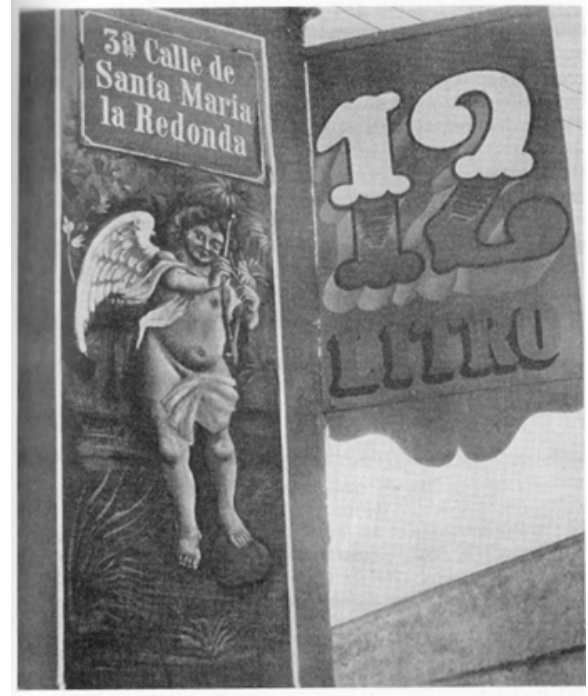

Brenner (1983: s/p)

Na imagem, o enquadramento traz a figura do cupido, localizado exatamente abaixo da placa com o nome da rua onde se localiza a pulqueria: "3a Calle de Santa Maria la Redonda". Ao lado dessa placa e da imagem do cupido, há os dizeres "12 litro". O recorte escolhido para a fotografia traz, neste caso, uma composição complexa: um nome de rua ligado ao cristianismo, uma imagem ligada à mitologia grega, o cupido, e um número que segue uma estética específica, com traços arredondados e tridimensionais. Note-se, portanto, a ligação de elementos que, a priori, fazem parte de diferentes universos: o cristão, o grego e o asteca, uma vez que se trata de uma pulqueria, um estabelecimento que tem na venda do 
pulque sua principal atividade. Novamente háfluidez, o novo criado com a fusão de diversos elementos. Na concepção de Warburg, "o papel da obra de arte [...] não é o de objeto passivo a ser contextualizado na cultura a partir de uma relação fixa" (Warburg citado em Bartholomeu 2010: 118). Ao contrário dessa fixidez, sua visão demandava um transitar, "seja na dimensão histórica, a partir do conceito de pathosformel, seja na dimensão da cultura, extrapolando, assim, os limites da história da arte tal como a concebemos classicamente" (118). O artista, segundo sua concepção, é amparado pela memória coletiva e individual. Desse modo,

faz-se necessário buscar a matriz que imprime na memória as formas expressivas da máxima exaltação interior, expressa na linguagem gestual com tal intensidade, que esses engramas da experiência emotiva sobrevivem como patrimônio hereditário da memória, determinando de modo exemplar o contorno criado pela mão do artista no momento em que os valores mais altos da linguagem gestual desejam emergir na criação por sua mão (Warburg 2010: 126).

Giorgio Agamben (2010) entende essa "ciência sem nome" de Warburg como uma "lufada de ar fresco" no trato com as imagens. "Nessa perspectiva, pela qual a cultura é sempre um processo de Nachleben, quer dizer, de transmissão, recepção e polarização, compreendemos por que Warburg devia fatalmente concentrar sua atenção no problema dos símbolos e de sua existência na memória social" (Agamben 2010: 136), entendendo a memória não como uma consciência, mas como uma "forma de conservação e de transmissão de energia, desconhecida do mundo físico" (136).

Na imagem em questão, pode-se pensar que a simples presença do cupido indica a memória individual e coletiva ali presente de dois modos: o primeiro pelo fato de o artista anônimo mexicano contratado para pintar a fachada da pulqueria ter pintado o cupido; o segundo pelo fato de, dentre centenas de pulquerias, esta, com a imagem do cupido, ter sido fotografada. O "patrimônio hereditário da memória", segundo a concepção warburguiana, se fez marcante, portanto, na mão do pintor e do fotógrafo.

Rivera tratou dessa questão das pulquerias enquanto uma arte viva e pública na edição número 6 da revista "Mexican Folkways", de abril/maio de 1926. Para ele, essa arte é uma das manifestações mais importantes da pintura mexicana, não de acordo com a concepção burguesa de arte, obviamente. Segundo Rivera, o mexicano é um colorista, o que remete à constante reconstrução dos murais coloridos de tais estabelecimentos; e os nomes das pulquerias são os melhores poemas sintéticos mexicanos. 
Brenner trabalha ao mesmo tempo com a simbologia das pinturas das pulquerias e os corridos. Afirma que corrido, "literalmente 'noticias de los tiempos' - es el nombre que se le da actualmente a la balada en México" (Brenner 1983: 198). Os corridos, como os murais, seriam pouco definidos pela cronologia, uma vez que se trata, muitas vezes, dos mesmos acontecimentos, ou de novas versões de acontecimentos já conhecidos. Brenner une estes dois elementos - corridos e pulquerias - pelo fato de os corridos terem justamente nas pulquerias sua maior audiência. "De la pobreza, poesía; del sufrimiento, canción: miles de cuentos anónimos atravesados por ritmos mexicanos que se emparejan con las galerías pintadas y que, como ellas, están animados por las mismas imágenes" (Brenner 1983: 199). Nessa poesia e musicalidade mexicanas destacam-se as vaciladas, palavra que, para Brenner, é intraduzível em qualquer outro idioma. Trata-se de

una caricatura sin moraleja. Vacilada es palabra del argot que define el hilarante trance ocasionada por la marihuana [...]. Este trance a servido como punto de comparación con cierto estilo, tono y actitud que permea toda la vida mexicana, y que hace de la vida y el arte una conciente caricatura (Brenner 1983: 203).

A característica central da vacilada é a dúvida. Dúvida que abarca tudo, que é irreverente e maliciosa, em que tudo é possível, ainda que se admita que razoavelmente não seja. A vacilada é pura fluidez. Ela se faz presente, por exemplo, nos nomes das pulquerias, como "Los recuerdos del porvenir". É também um elemento mestiço, uma vez que carrega a ironia indígena e a picaresca espanhola, num jogo de várias perspectivas. Para Brenner, tudo parte da arte.

\section{México moderno: a difusão das artes mexicanas}

"Recuento". Este é o título do primeiro capítulo da terceira parte do livro de Brenner, justamente o que trata do México moderno, ou seja, do momento em que o livro foi pensado e construído, do momento que Brenner, Modotti e Weston viveram. Ao tratar do presente, Brenner dá total destaque às pinturas murais. Novamente, portanto, pensava a vida a partir da arte. Ela afirma que, de modo individual ou coletivo, ocorreu, nesse período, um encontro espiritual entre os homens e seu país. Tais homens descobriram (ou redescobriram?) que possuíam uma tradição indígena que era uma herança racial americana de essencial grandeza. Isso fez com que, pouco a pouco, esses homens fossem regressando ao México. Para ela, um dos maiores que regressaram foi Gamio. Ao falar de Gamio, Brenner ressalta a concepção de forjar pátria. 
La forja de la patria, dijo Gamio, no puede consistir como antes en los pedantes e inútiles esfuerzos por "civilizar" al indio e "incorporarlo" al progreso moderno; en lugar de eso, debe intentarse la reeducación de quienes estamos ya "civilizados" (Brenner 1983: 263).

Há de se pensar, aqui, se este era de fato o discurso defendido por Gamio ou se se trata da forma como Brenner interpretou os seus dizeres. Afinal, conforme mencionado, Gamio (1916), em "Forjando Pátria. Pro nacionalismo", afirmou a necessidade de que houvesse uma aproximação com a cultura indígena - este sempre visto como "o outro" - para que ele pudesse ser integrado na cultura nacional, deixando claro que tal aproximação deveria ser pontual, chegando a afirmar que "no debe exagerarse a un extremo ridículo el acercamiento al índio" (Gamio 1916: 178). Brenner, dessa forma, destacou a defesa de Gamio de que os governos deveriam estudar sua gente e seu território, analisando-os de modo integrado, para que, com isso, conseguissem entender seus povos. "Son las leyes incomprensibles para los nativos? Cámbiense las leyes. [...] Hay que dejar que todo lo nativo se a la unidad básica del ideal económico y cultural. Es esto una vuelta a la barbarie? Si lo es, mejor el barbarismo que la esterilidad" (Brenner 1983: 264).

Segundo Brenner, Gamio postulava um bem-estar baseado não em melhorias econômicas, mas em mais escolas e melhores condições sanitárias. "Decía que la tierra debía serle regresada al campesino porque su investidura le significaba mucho más que el bienestar material. Entregarle la tierra significaba para él el reconocimiento de su razón de ser" (Brenner 1983: 265). Percebe-se, contudo, o quanto essa narrativa de Brenner se choca com o discurso de Gamio referente ao que ele entendia como progresso, pois, ao mesmo tempo em que abraçava o relativismo cultural de Boas, afirmando que os grupos humanos seguem diferentes ritmos de vida, defendia que, por meio de intervenções realizadas a partir do conhecimento sobre o modo de vida dos indígenas, eles poderiam atingir o progresso do modo de vida europeu, conquistando bem-estar econômico, ou seja, o discurso de Gamio é contraditório e Brenner segue a parte desse discurso com a qual concorda, deixando de lado toda a questão de hierarquização de culturas presente nos escritos de Gamio. É nesse sentido que defendemos que a narrativa de "Ídolos..." ora se aproxima, ora se distancia do discurso de Gamio, assim como da teoria de Vasconcelos.

Para Brenner, o regresso aos valores indígenas, artísticos e espirituais, "lo que es una descripción simplificada del arte mexicano moderno" (Brenner 1983: 266), ocorreu em função de um rompimento com os valores europeus, principalmente os franceses, e da violência que implicou derrotar o latifúndio. 
Ao tratar dos artistas, Brenner destaca que poucos são indígenas puros e que quase todos viveram e estudaram vários anos na Europa. Para a autora, os iniciadores desse renascimento mexicano eram inovadores conscientes que, principalmente a partir de 1921 - considerada a data final da revolução armada - fizeram uma revolução na arte.

Este movimiento (El Renacimiento Mexicano) fue el producto de artistas que volvían de la Europa cínica de la pos-guerra al México de la energía posrevolucionaria; luego se desborda en proyectos utópicos. Se compartían los sentimientos de libertad, exigencia de derechos y vida nueva. La raza de bronce podía - al fin - deshacerse del dominio extranjero. El ser humano autóctono y sus modos de vida política podían convertirse en una meta nacional digna. Los artistas que se creyeron intérpretes de las massas, le otorgaron sustancia y colorido a la emoción que todo lo impregnaba. De ali deriva el ABC del arte mexicano moderno: que las epidermis morenas y los cuerpos indígenas podían ser más hermosos, y sin duda podían representar con mayor hermosura que el ideal extranjero de la piel blanca y el pelo rubio (Azuela 2006: 79).

Naquele mesmo ano, de 1921, Vasconcelos havia sido nomeado Secretário da Educação pelo presidente Obregón. Muitos dos planos de Vasconcelos se basearam na atuação incansável de artistas, com destaque para os pintores muralistas. No que diz respeito ao ensino, professores passaram a utilizar, muitas vezes, sistemas baseados na arte nativa, distanciando-se, cada vez mais, do humanismo francês. O que ocorria nas escolas era semelhante ao que ocorria na produção artística: "todo el mundo se había lanzado a la calle a mirar a México" (Brenner 1983: 272). Nesse meio, a obra de crianças nas escolas livres tem grande destaque. Para Brenner, o que parecia o resultado de um gênio anormal ou a descoberta pedagógica do século era, na realidade, resultado do fato de a arte ser um hábito nacional que sempre atraiu os mexicanos. "Dibujo y pintura se convirtieron en el lenguaje adoptado para la enseñanza de otras matérias, desde los princípios de la higiene hasta la geografía" (Brenner 1983: 273).

A arte era, de fato, a revolução. Por definição, os murais pintados nas paredes dos prédios públicos devolveriam à arte o significado social e a função que havia tido em outros períodos. Para Brenner, tratava-se da forma mais óbvia e legítima da grande arte nativa, a qual, em sua visão, alcançou uma profundidade estética mais acentuada, inicialmente com Siqueiros. ${ }^{13}$ Para Siqueiros, os mexicanos deveriam abraçar suas tradições: pintar suas próprias imagens, identificar-se em espírito com sua extraordinária herança artística e com sua descendência. Esse identificar-se com sua origem e descendência vai ao encontro da ideia de Brenner de que, no México, 
como em nenhum outro lugar do mundo, a arte está ligada intimamente ao destino do povo. Brenner, então, destaca a criação e a atuação do Sindicato de Pintores e Escultores. Para ela, esse grupo operou com dois fins, que podem, contudo, ser entendidos como um só: a construção de uma arte nativa e a reintegração dessa arte à sua função social. Em ambos os fins é possível constatar a ênfase dada ao caráter pedagógico da imagem: ela deve construir, instruir e politizar.

El arte por el arte mismo - proclamaban - es una falácia estética; el arte para el Pueblo es también una frase inconsistente, hipócrita y sentimental. El arte es algo que necesariamente pertenece al Pueblo, y no un concepto abstracto ni un vehículo para explotar fantasias (Brenner 1983: 283).

A arte mural mexicana, desse modo, é encarada como uma arte coletiva. Apesar de poderem ser identificados certos traços individuais, para os pintores não parecia importante precisar quando se tratava de uma ideia comum a todos ou se seria de algum deles em específico.

Siqueiros, Charlot e Revueltas son inconfundíbles pese a que todos pintaron casi literalmente todos los cuadros de los otros. Una noche en que Siqueiros se había retirado temprano - no recuerdo se a dormir, a dar una conferencia o a escribir el editorial para El Machete -, su compañero Xavier Guerrero le pintó una cabeza a uno de sus cuadros inconclusos. Cuando Siqueiros la vio, exclamó encantado: Magnifico! O la pinté dormido, o se trata de un milagro! (Brenner 1983: 284).

Era comum que vários homens trabalhassem em um mesmo mural, simultaneamente. Os contratos eram feitos de acordo com as dimensões da parede e em dias de trabalho de oito horas. Em média pagavam-se oito pesos por dia de trabalho. Os primeiros contratos foram assinados em 1922. Muitos dos artistas, quando não estavam pintando, escreviam para o "El Machete" ou ensinavam nas escolas. Brenner destaca, então, que, mesmo nas horas de lazer, era comum estarem juntos na casa de Weston e Modotti.

Como não poderia deixar de ser, Brenner trata das críticas que, com o tempo, foram direcionadas aos murais e aos muralistas, que eram acusados, dentre outras coisas, de serem bolcheviques que estavam depreciando o México. Vasconcelos, nesse mesmo contexto, em meados de 1924, foi acusado de dilapidar os cofres públicos, sendo cobrado para que parasse com o absurdo que significava patrocinar a pintura mural. Em meio a essas críticas, o Sindicato de Pintores e Escultores publicou um manifesto em protesto, que Brenner colocou em sua obra. 


\section{Protesta}

Se está llevando a cabo una campaña en contra del actual movimiento mural mexicano. A este movimiento se le ataca por ignorância y envidia. Y para hacer el golpe más infame y calculado, se hace aparecer al movimiento deliberadamente mesclado con acusaciones personales. Se nos lanza la piedra del dinero, salpicada con cargos de DESPILFARRO, PRECIOS FABULOSOS Y ENORME GANANCIAS, etcétera. El pintor que más gana en la Secretaria recibe exactamente el salario del artesano que nivela muros por metro cuadrado. El público queda invitado a comprovar esto en los contratos de los pintores en la Secretaria de Educación Pública.

Esta protesta no es una desculpa.

Estamos convencidos de que el presente movimiento de pintura en México es la expresión y afirmación de nuestra nacionalidade (Brenner 1983: 295-296).

As discussões, a partir da divulgação desse manifesto, se acirraram. Os murais, pouco depois, foram alvo de vandalismo e destruição. Os defensores de tais ações, que se autonomeavam guardiões do humanismo de Diaz, proliferavam discursos defendendo que os estudantes necessitavam de ambientes que colaborassem para a contemplação espiritual, e que, se a Secretaria lhes impunha aquela arte vulgar, eles estavam em seu direito de protestar desse modo. Diante da situação, residentes estrangeiros no México entregaram uma petição com mais de duzentas assinaturas protestando em nome da arte, "que no es una propiedad nacional, sino internacional" (Brenner 1983: 296), para que os murais fossem protegidos. A proteção consistiu em uma alteração no material que deveria ser produzido a partir de então. Assim, cancelaram-se os trabalhos na Escola Preparatória. Pouco depois, ainda em 1924, Vasconcelos sairia da Secretaria de Educação, com a mudança de presidente, e toda essa produção seria substituída pela indiferença do novo Secretário, mais preocupado, nas palavras de Brenner, com as pinturas de gênios do que com o trabalho de pintores maduros. "Por su parte, el nuevo director del Departamento de Bellas Artes pasó a la historia de la estultícia declarando que: 'La primera cosa que haré será ordenar que se borren esos horribles frescos'" (Brenner 1983: 298). O Sindicato também se dissolveu. Apesar de todas essas alterações e das depredações, a arte produzida por esses pintores havia criado nova tradição e nova perspectiva.

Após trabalhar com os artistas de modo coletivo, Brenner discorre sobre cada um deles individualmente. Cada capítulo passa, então, a ter o nome do artista analisado. David Alfaro Siqueiros, José Clemente Orozco, Diego Rivera e Francisco Goitia são alguns deles. De Siqueiros, Brenner destaca 
suas inúmeras atuações: integrante ativo do Sindicato, pintor, cabeça de comitê de greve etc. Nas palavras de Brenner, o caminho de Siqueiros "sigue siendo el del hombre que elige ser extraordinário en lugar de famoso" (Brenner 1983: 307). Orozco, para a autora, é o artista do contraste, o detentor do hábito do sofrimento. Suas obras deveriam, a seu ver, ser entendidas com o olhar. Sobre Rivera, afirma que, para muita gente, a palavra "massa" se associa intimamente a ele. "Uno va y viene, un mes, un año, más años y cada vez que se regresa a México se recibe la misma sensación de perennidad, la permanente afirmación de las montañas, las pirámides y Rivera, que desafían al tempo" (Brenner 1983: 321). Ao tratar de Goitia, ela afirma que ele é o artista que mais essencialmente expressou a civilização mexicana como um todo, devido à paixão pelo simbólico, à serenidade, à intensa humildade e à capacidade de amor. Para ele, era necessário que um quadro com uma criança faminta estivesse no escritório do Subsecretário, "como diciendo: 'mira, no pierdas el sentido de la realidad, aqui estoy yo'" (Brenner 1983: 342).

No último capítulo de "Ídolos...", "Revolución y Renacimiento", Brenner afirma que no intervalo de tempo de uma geração o México voltou-se para si mesmo. Em sua visão, a arte foi a grande propulsora desse processo, pois se trata de um país onde se "abre una escuela de escultura antes de pensar en un Tribunal Juvenil, y que pinta los muros de sus edificios mucho más aprisa de lo que organiza un Banco Federal" (Brenner 1983:363). Para Brenner, no que diz respeito aos bens do mundo, o México é um país pobre, mas abundante no que ela denominou de três heroísmos: emoção, pensamento e expressão.

Zapata cayó asesinado y las tierras no han sido devueltas a su gente, como él lo soñó; Carrilo Puerto fue traicionado y sus mayas no están más saludables y prósperos desde su muerte; la crítica social de Orozco no ha tenido resultados prácticos que se puedan medir; el Sindicato desapareció sin haber creado protección económica para los artistas. Pero en todas esas tareas quedaron plasmados los tres heroísmos, y eso parece suficiente (Brenner 1983: 365).

"Ídolos..." tinha como objetivo dar visibilidade à cultura mexicana. Para isso, visava atingir mexicanos e estrangeiros. Sobre os mexicanos, vale destacar que censos realizados na transição do século XIX para o XX apontavam um significativo número de analfabetos: no ano de 1895, 82,1\% dos mexicanos eram analfabetos; em 1950, 42,6\% da população ainda não era alfabetizada (Robles; \& Navarro 2012: 10). Desse modo, pode-se dizer que as imagens produzidas naquele período tinham a missão de tornar visível e, portanto, inteligível parte da história do México. Segundo Vasquez, a produção artística mexicana do período pós-revolucionário apresentava, dentre outros fatores, o desejo de transmitir ao povo iletrado o núcleo 
fundamental do que fora denominado de Renascimento Cultural. Isto não significa, contudo, que as imagens visavam somente aos letrados, afinal, as imagens podem afetar tanto os iletrados quanto os alfabetizados e os próprios intelectuais, incluindo aí o círculo compreendido pelos leitores efetivos do livro de Brenner.

No caso de "Ídolos..." além de visibilidade, pode-se dizer que as imagens deram perenidade ao discurso de Brenner. Perenidade que também era o objetivo das artes como um todo produzidas no México naquele contexto, haja vista os murais confeccionados em paredes de prédios públicos. "Ídolos..." tem 92 imagens. Destas, 40 são fotografias. As demais se trata de ilustrações e ex-votos, principalmente. Do total de imagens, nove referem-se a produções do período pré-hispânico, dez ao colonial, e todas as demais, 73 imagens, ao período moderno. Este dado, mais uma vez, pode ser utilizado para entender o quanto Brenner se valeu da narrativa e das imagens para pensar sobre o presente mexicano, ou seja, sobre a década de 1920, a partir das ligações que esse período tinha e tem com o passado mexicano. Nesta perspectiva, as fotografias de "Ídolos..." se aproximam do objetivo da pintura mural, feitas no mesmo contexto, de produzir algo que criasse visibilidade à história e à tradição mexicanas, ligando-as ao presente da nação.

Capa de "ídolos tras los altares"

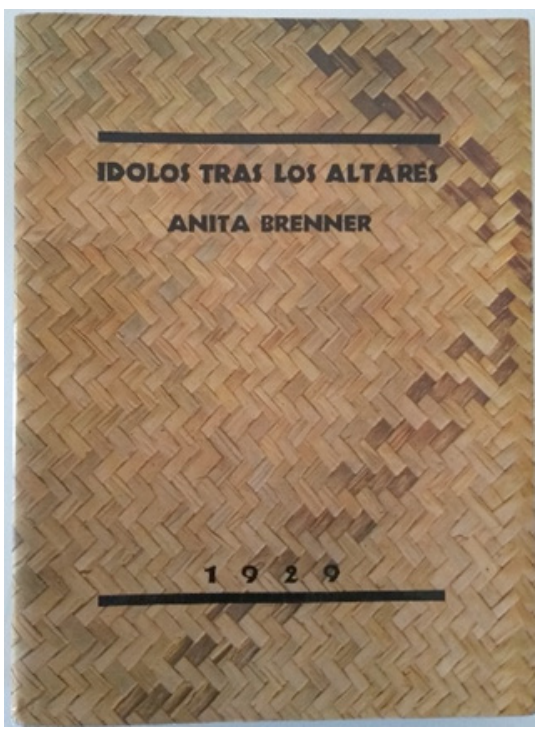

(Brenner 1983) 

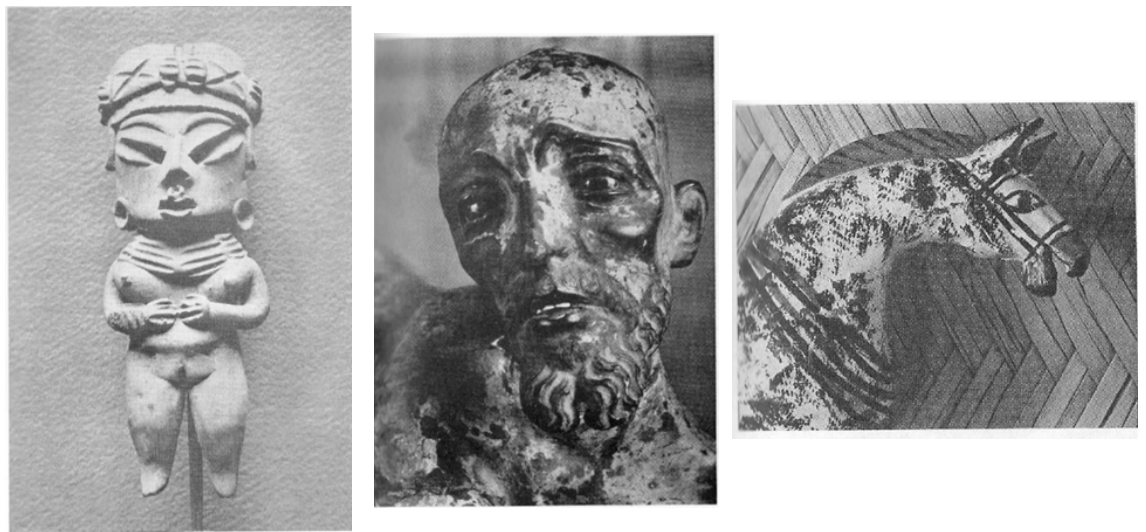

(Brenner 1983: s/p)

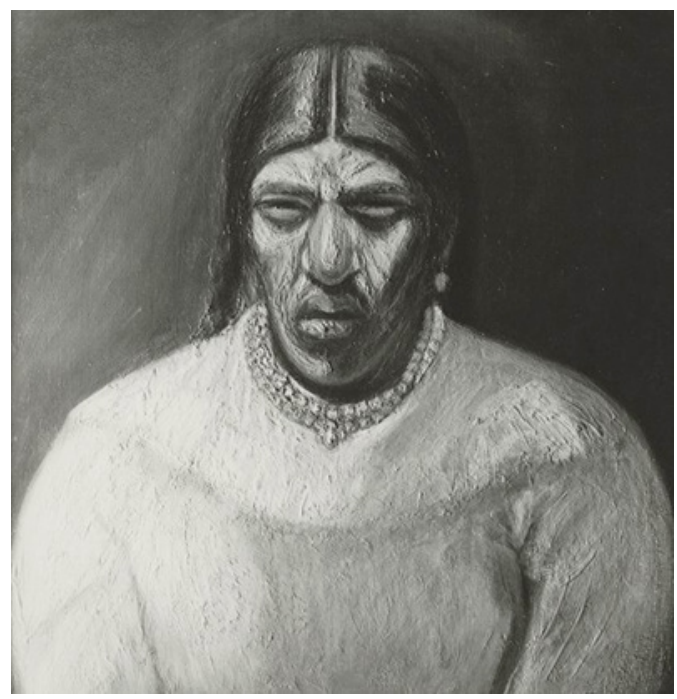

(Brenner 1983: s/p) 
Recebido em: 23 de julho de 2019

Aprovado em: 06 de novembro de 2019

Fabiane Tais Muzardo é Doutora em História pela Universidade Federal do Paraná (UFPR/2019), Mestre em História pela Universidade Estadual de Londrina (UEL/2010) e Graduada em História pela Universidade Estatual Paulista (Unesp/2006). É docente na Universidade Norte do Paraná desde 2010.

https://orcid.org/0000-0002-4496-7817

E-mail: fabianemuzardo@yahoo.com.br

\section{Notas}

1 Azuela é pesquisadora do "Instituto de Investigaciones Estética" da UNAM, o qual possui o acervo "Tina Modotti".

2 Gamio foi um antropólogo mexicano nascido em 1883. Foi o criador da teoria indigenista. A principal obra de Gamio, intitulada "Forjando Pátria. Pro nacionalismo", escrita em 1916, integra os debates teóricos que coexistiram na tentativa de (re) construir o México no período pós-revolucionário.

3 Vasconcelos nasceu em Oaxaca, no México, no ano de 1882. Colaborou ativamente para a fundação do "Ateneo de la Juventude". Foi reitor da Universidade Nacional do México, atual UNAM, entre os anos de 1920 e 1921. Em 1921 se tornou o primeiro secretário da Educação no México, cargo que ocupou até 1924. Dentre outras obras, escreveu "Ulisses Criollo" e "La Raza Cósmica".

4 Vale lembrar que, em meados de 1930, a mestiçagem e as nuances da cultura nacional também eram temas de discussões no Brasil, principalmente com as produções de Gilberto Freyre. Analisando os escritos de Freyre, Jessé Souza afirma que a "igualdade política e econômica jamais foi o princípio mais importante do sociólogo Gilberto Freyre. Ao inverso, sua atenção esteve sempre voltada a perceber formas de integração harmônica de contrários, interdependência e comunicação recíproca entre diferentes, sejam essas diferenças entre culturas, grupos, gêneros ou classes" (Souza 2000: 71). 
5 Em 1909, Vasconcelos, Alfonso Reyes e Pedro Henrique Ureña fundaram o "Ateneo de la Juventude". Esse grupo criticava a filosofia oficial mexicana, determinada pelo governo ditatorial de Porfirio Diaz, o positivismo; taxando-a de extremamente sistemática. Desse modo, baseando-se em leituras consideradas inúteis pelos mexicanos que seguiam essa filosofia oficial, os membros do "Ateneo" passaram a seguir as ideias de teóricos como Platão - que se tornou a principal referência do grupo -, Kant, Schopenhauer e Nietzsche. Inicialmente, os integrantes do "Ateneo" diziam não desejar ocupar posições diretivas no país, o que não se manteve por muito tempo, afinal, poucos anos depois, Vasconcelos se tornaria reitor da Universidade Nacional e, posteriormente, Secretário da Educação.

6 "Mexican Folkways" foi uma revista de arte que visou projetar a cultura mexicana para o povo mexicano e para o exterior. A revista foi publicada entre os anos de 1925 e 1937. Todas as edições foram editadas em dois idiomas: espanhol e inglês. Nas primeiras edições, os textos vinham na íntegra em inglês e, depois, em espanhol. A partir de 1927, houve uma alteração da estética da revista, que passou a ter duas colunas: a coluna do lado esquerdo era escrita em espanhol e a da direita em inglês. Parece que a revista, a partir de então, passou a dar mais importância ao idioma espanhol do que ao inglês. Brenner e Modotti participaram dessa produção.

7 Giorgio Vasari publicou, no ano de 1550, o livro "Vida dos artistas", considerado a obra inaugural da História da Arte. No livro, Vasari escreveu sobre a vida e a obra dos principais artistas do Renascimento italiano, contando uma série de anedotas.

8 A vacilada é uma máscara mestiça na qual se fundem aspectos indígenas e espanhóis, de modo a não ser possível distinguir se o seu gesto é de alegria ou de dor. Desse modo, a vacilada liga-se à escolha.

9 Contrapondo-se à concepção de pureza, Warburg trabalha com a ideia de hibridez e de transição. Ao analisar os índios Pueblo, por exemplo, em artigo intitulado "Images from the Region of the Pueblo Indians of North America" (1995), Warburg afirma que eles "claramente ya no son primitivos dependientes de sus sentidos, para los cuales ninguna acción directa hacia el futuro puede existir; pero tampoco son europeos tecnologicamente seguros, para quienes se supone que los eventos futuros están organica o mecánicamente determinados. Aquéllos permanecen en el terreno medio entre magia y logos y su instrumento de orientación es el símbolo" (Warburg 1995:17)

10 Corrido é uma narrativa popular mexicana desenvolvida em forma de versos que pode ser cantada. Os temas variam desde a história do país até eventos políticos e cotidianos. Na revista Forma, corrido foi definido como: "Canción característica del pueblo mexicano, compuesta por él mismo. Casi siempre consta de innumerables estrofas octossílabas, rimadas o asonantadas, que relatan sucesos de interés colectivo, inspirados en desgracias o injusticias sociales. Glosan a veces al héroe o al bandido. A menudo son el recordatorio de acontecimientos que sacuden el espíritu popular. La música no es siempre de una melodia melancólica. Y consta, por lo regular, de dos partes. Estas se repiten alternativamente hasta apurar las estrofas del poema. La melodía es, pues, "corrida". De ahí la designación de esta palpitante y personalísima 
canción mexicana. Los cantores populares repiten las canciones acompañadas de guitarra, y mantienen el interés público de la misma manera que los rápsodas o los antiguos juglares". Canção característica do povo mexicano, composta por ele mesmo. Quase sempre consta de inúmeras estrofes octossílabas rimadas ou assonantadas, que relatam sucessos de interesse coletivo, inspirados em desgraças ou injustiças sociais. Parodiavam, às vezes, o herói ou o bandido. Muitas vezes, é a lembrança do evento que agita o espírito popular. A música não é sempre uma melodia melancólica. Geralmente consiste em duas partes. Estas se repetem alternadamente até que as estrofes do poema sejam aceleradas. A melodia é, portanto, "corrida". Daí a designação desta música mexicana palpitante e muito pessoal. Os cantores populares repetem as músicas acompanhadas de violão e mantêm o interesse público da mesma forma que as rapsódias ou os antigos trovadores (Corrido de la Revolución, Forma, v. 1 , n. 5 , p.: 43).

11 Pulquerias são estabelecimentos comerciais especializados na venda do pulque.

12 Maguey é uma planta originária do México, considerada um dos símbolos do país. Do maguey se produz o agave, utilizado na fabricação do pulque, bebida alcóolica tradicional de consumo comum nas pulquerias e que tem espaço, também, em rituais religiosos.

13 Siqueiros nasceu no México no ano de 1896. Foi um dos grandes pintores muralistas mexicanos. Sua vida foi marcada por grande ativismo político. 


\section{Referências bibliográficas}

AGAMBEN, Giorgio. 2007. Estâncias. A palavra e o fantasma na cultura ocidental. Belo Horizonte: Editora UFMG.

. 2010. "Aby Warburg e a ciência sem nome". Revista Arte\&Ensaios, n. 19. PPGAV-EBA/UFRJ.

AZUELA, Alicia. 2006. "Ídolos tras los altares, piedra angular del renacimiento artístico mexicano". In: A. Hernandéz (org.), Anita Brenner. Visión de una época. España: Editorial RM. pp. 61-102.

BARTHOLOMEU, Cesar. 2010. "Dossiê Warburg". Revista Arte\&Ensaios, n ${ }^{\circ}$ 19. PPGAV-EBA/UFRJ.

BRENNER, Anita. 1983. Ídolos tras los altares. México: Domés.

DIDI-HUBERMAN, Georges. 2013. A Imagem sobrevivente. História da arte e tempo dos fantasmas segundo Aby Warburg. Rio de Janeiro: Contraponto.

FOCILLON, Henri. 2010. A vida das formas. Seguido do elogio da mão. Lisboa: Edições 70.

GAMIO, Manuel. 1916. Forjando Patria. Pro nacionalismo. Ciudad de México: Librerái de Porrúa Hermanos.

VASCONCELOS, José. 1997. The Cosmic Race. La Raza Cósmica. United States of America: The Johns Hopkins University Press. . 1925. "El aspecto Utilitario del Folklore". Mexican Folkways, 9-10. GUERREIRO, Antonio. 2012. As imagens sem memória e a esterilização da cultura. Disponível em: http://www.porta33.com/eventos/content_eventos/ Antonio_Guerreiro_Aby_Warburg/ Seminario_Antonio_Guerreiro.html. Acesso em 02/07/20199.

GRUZINSKI, Serge. 2007. El pensamiento mestizo. Cultura ameríndia y civilización del Renacimiento. Barcelona: Bolsillo. 2006. A guerra das imagens: de Cristóvão Colombo a Blade Runner (1492-2019). São Paulo: Companhia das Letras.

"Idols Behind Altars". 1929. Mexican Folkways: s/p.

MANJARREZ, Maricela González Cruz. 1999. Tina Modotti y el muralismo mexicano. Ciudad de México: Universidad Nacional Autónoma de México.

MEDINA, Andres. 1974. "Antropologia e el indigenismo. Los compromisos contradictorios de la ciencia en México". Revista de la Universidad de México, 13-20.

MONDZAIN, Marie-José. 2015. Homo spectator. Ver, Fazer ver. Lisboa: Orfeu Negro.

MONSIVÁIS, Carlos. 2006. "Anita Brenner y el Renacimiento Mexicano". In: A. Hernandéz (org.), Anita Brenner. Visión de una época. España: Editorial RM. pp. 19-40.

ROBLES, José Narro; \& NAVARRO, David Moctezuma. 2012. "Analfabetismo e México. Una deuda social". Revista Internacional de Estadistica y Geografia, v. 3, n. 3: 5-17.

RAMÍREZ, Guillermo Castillo. 2013. "Imaginarios de pueblos indígenas y nación a fines del México revolucionario. Forjando Patria: génesis del ideario del indigenismo del siglo XX". Margen, n. 70:1-10.

SAN JOSÉ VÁZQUEZ, Eduardo. 2009. "Ídolos tras los altares: la recuperación del México prehispánico y colonial en la obra de Anita Brenner". Tema y variaciones de literatura: México prehispánico y colonial: miradas contemporâneas, $\mathrm{n}^{\circ}$ 32: 69-93. 
SOUZA, Jessé. 2000. "Gilberto Freyre e a singularidade cultural brasileira". Rev. Sociol. USP, 69-100.

TRONCOSO, Alberto del Castillo. 2006.

“Imágenes y representaciones de la niñez em México a princípios del siglo XX". In: A. Reyes (org.), Historia de la vida cotidiana en México. Ciudad de México: El Colégio de México/Fondo de la Cultura Económica. pp. 83-115.
UGALDE, Nadia. "Introducción". 2006. In: A. Hernandéz (org.), Anita Brenner. Visión de una época. España: Editorial RM. pp. 9-18.

WARBURG, Aby. 1995. Images from the Region of the Pueblo Indians of North America. Londres: Cornell University Press.

"Mnemosyne". 2010. Revista Arte\&Ensaios, n¹9, PPGAV-EBA/ UFRJ. 
"ÍDOLOS TRAS LOS ALTARES":

A (RE)CONSTRUÇÃO DA ARTE MEXICANA NO PERÍODO PÓSREVOLUCIONÁRIO

\section{Resumo}

Anita Brenner, Tina Modotti e Edward Weston viajaram pelo interior mexicano, no início dos anos 1920, para produzir um registro escrito e imagético sobre a arte popular e religiosa. Desse projeto resultou o livro "Ídolos tras los altares", publicado pela primeira vez nos Estados Unidos no ano de 1929. Esse artigo visa analisar essa obra a partir dos diálogos que ocorriam no México sobre os indígenas e a questão cultural, no pós-revolução. Defende-se que tal obra ora se aproxima da teoria indigenista, de Manuel Gamio; ora da mestiçagem, de José Vasconcelos; ora cria algo novo, mais próximo a teorias antropológicas atuais, como a de Serge Gruzinski. Em “Ídolos...", Brenner mescla crônicas populares, resultados de sua observação, descobertas e suas próprias lembranças, em uma narrativa que, apesar da organização cronológica da obra, tem o período pós-revolucionário como referência.

Palavras-chave: "Ídolos tras los altares"; Anita Brenner; México; Arte; Revolução.

\author{
"ÍDOLOS TRAS LOS ALTARES": \\ THE (RE)CONSTRUCTION OF \\ MEXICAN ART IN THE POST- \\ REVOLUTIONARY PERIOD
}

\section{Abstract}

Anita Brenner, Tina Modotti and Edward Weston traveled throughout the mexican interior in the early 1920's, producing a written and imagetic record of popular and religious art. From this project resulted a book, "Ídolos tras los altares", published first in the United States, in 1929. This article aims to analyze this book, starting from the dialogues that occurred in post-revolutionary Mexico concerning indigenous and cultural issues. It argues that this book sometimes approaches Manuel Gamio's Indigenist theory, while sometimes it comes closer to the miscegenation, of José Vasconcelos; at other times it creates something new, close to current anthropological theories, such as those of Serge Gruzinski. In“Ídolos...”, Brenner blends popular chronicals, the results of the observation, discoveries and her own memories, in a narrative that, despite the chronological organization of the book, has the post revolution period as its reference.

Key words: "Ídolos tras los altares"; Anita Brenner; Mexico; Art; Revolution. 
“ÍDOLOS TRAS LOS ALTARES":

LA (RE)CONSTRUCCIÓN DEL

ARTE MEXICANO EN EL PERÍODO

POSREVOLUCIONARIO

\section{Resumen}

Anita Brenner, Tina Modotti y Edward Weston viajaron por el interior de México a principios de la década de 1920 para producir un registro escrito e imaginativo sobre el arte popular y religiosa. Este proyecto dio como resultado el libro "Ídolos tras los altares", publicado por primera vez en los Estados Unidos en 1929. El objetivo de este artículo es analizar esta obra a partir de los diálogos que tuvieron lugar en México sobre los indios y la problemática cultural en el periodo posrevolucionario. Se argumenta que este trabajo a veces se acerca a la teoría indigenista de Manuel Gamio; a veces al mestizaje, de José Vasconcelos; a veces crea algo nuevo, más cercano a las teorías antropológicas actuales, como la de Serge Gruzinski. En “Ídolos ..." Brenner mezcla crónicas populares, resultados de sus observaciones, descubrimientos y sus propios recuerdos, en una narrativa que, a pesar de la organización cronológica de la obra, tiene como referencia el período posrevolucionario.

Palabras clave: "Ídolos tras los altares"; Anita Brenner; México; Arte; Revolución. 